\title{
Role of the macula densa in the control of renal renin gene expression in two-kidney/one-clip rats
}

\author{
Karin Schricker ${ }^{1}$, Marlies Hamann ${ }^{1}$, Brigitte Kaissling ${ }^{2}$, Armin Kurtz ${ }^{1}$ \\ ${ }^{1}$ Physiologisches Institut der Universität Regensburg, Postfach 1010 42, D-93040 Regensburg, Germany \\ ${ }^{2}$ Anatomisches Institut der Universität Zürich, Switzerland
}

Received August 16, 1993/Received after revision November 22, 1993/Accepted November 23, 1993

\begin{abstract}
This study was designed to examine whether macula densa function is involved in the changes of renal renin gene expression upon acute hypoperfusion of one kidney. To block macula densa function, rats with free access to salt and water were subcutaneously infused with furosemide ( $12 \mathrm{mg} /$ day) for 6 days. Then, 4 days after the start of the infusion, the left renal arteries were clipped with $0.2-\mathrm{mm}$ silver clips and renin mRNA levels in ipsilateral and contralateral kidneys, as well as plasma renin activities (PRA), were determined $48 \mathrm{~h}$ after clipping. In non-clipped animals furosemide increased PRA from 10 to $47 \mathrm{ng}$ angiotensin $\mathrm{I} \cdot \mathrm{h}^{-1} \cdot \mathrm{ml}^{-1}$ and raised renin mRNA levels in both kidneys 2.5 -fold. In vehicle-infused animals, clipping of the left renal artery increased PRA to $37 \mathrm{ng}$ angiotensin $\mathrm{I} \cdot \mathrm{h}^{-1} \cdot \mathrm{ml}^{-1}$ and led to a 5-fold rise of renin mRNA levels in the ipsilateral kidneys and to a suppression to $20 \%$ of the control values in the contralateral kidneys. PRA values in clipped and furosemide-infused animals were $45 \mathrm{ng}$ angiotensin $\mathrm{I} \cdot \mathrm{h}^{-1} \cdot \mathrm{ml}^{-1}$. In these animals renin mRNA levels increased in the ipsilateral kidneys to similar $a b$ solute values as in vehicle-infused rats, whilst contralateral renin mRNA levels fell to about $25 \%$ of the respective controls. These findings indicate that the stimulations of renin gene expression by inhibition of macula densa salt transport and by renal artery clipping are not additive, suggesting that the macula densa mechanism may participate in the stimulation of renin gene expression upon hypoperfusion. The macula densa mechanism, however, appears to be not essentially involved in the suppression of renin gene expression in the contralaterals to stenosed kidneys.
\end{abstract}

Key words: Furosemide - Juxtaglomerular cells - Renin secretion

\section{Introduction}

There is increasing evidence that acute and chronic hypoperfusion of one kidney causes characteristic changes not only of the renin content (for veview [22]), but also of the levels of renin mRNA, in such a way that renin mRNA levels increase ipsilaterally and decrease contralaterally $[13,15,19]$. Since the regulation of the renin gene at the cellular level is in general only poorly understood, the mechanisms responsible for this differential regulation of renin gene expression in the kidneys in beings with unilateral renal artery stenosis have not yet been elucidated. In particular, it is unknown how much the macula densa mechanism is involved in this process. Meanwhile it has been well established that the macula densa exerts a negative control function on renin secretion $[9,11,20]$ and further evidence suggests that the macula densa function participates in the control of renin secretion by the renal perfusion pressure [20]. There is accumulating evidence that inhibition of macula densa function by loop diuretics such as furosemide not only stimulate renin secretion but also renin gene expression $[1,3,6,12]$ even in salt-balanced rats [14]. These findings prompted us to examine a possible participation of the macula densa mechanism in the change of renal renin gene expression upon unilateral renal artery stenosis for the following reasons.

Hypoperfusion of a kidney below the autoregulatory range of glomerular filtration will decrease the delivery of $\mathrm{NaCl}$ to the macula densa and thus inactivate the macula densa mechanism and could therefore increase renin gene expression. A compensatory increase of glomerular filtration in the contralateral kidney [17], on the other hand, could activate the macula densa mechanism and thus contribute to the suppression of renin mRNA levels in this organ.

It appeared reasonable to us, therefore to examine a possible involvement of the macula densa in this context. As an experimental model with inhibited macula densa salt transport we used rats that were chronically infused with furosemide and that had free access to salt 
and water. This manœuvre has recently been demonstrated to balance salt and water losses and thus to maintain a normal blood pressure and sodium balance [8]. Unilateral renal hypoperfusion was induced by clipping one renal artery (two-kidney/one-clip model). As an estimate for renin gene expression renin mRNA levels were measured by an RNase protection assay.

The results obtained suggest that the macula densa mechanism is likely to be involved in the enhancement of renin gene expression in the stenosed kidney, but not in the suppression of renin gene expression in the contralateral kidney.

\section{Materials and methods}

Animals. Male Wistar rats ( $n=20$, Charles River Wiga, Sulzfeld, Germany) weighing $140-160 \mathrm{~g}$ were kept in metabolic cages. They were fed standard chow and two bottles of drinking solution were equally available, one containing tap water, the other a salt solution of $0.8 \% \mathrm{NaCl}$ and $0.1 \% \mathrm{KCl}$. Body weight, drinking input and urinary output were measured every day. For the first 4 days of the experiment all animals were kept under the same conditions. Then osmotic pumps (2 ML1; Alzet, Palo Alto, USA) were implanted in the neck subcutaneously (day 0 ). In ten control animals the pumps were filled with $0.9 \% \mathrm{NaCl}$, in ten furosemide-treated animals with $2 \mathrm{ml}$ diacetadozol (Dimazon; Hoechst, Frankfurt, Germany) equivalent to $50 \mathrm{mg} / \mathrm{ml}$ furosemide. The delivery rate of the pumps was $10 \mu \mathrm{l} / \mathrm{h}$, thus the daily dosage of furosemide was $12 \mathrm{mg}$ per animal. The capacity of the pumps had been designed for 7 days. To guarantee a constant drug effect during the experiment, the pumps were primed in vitro for at least $4 \mathrm{~h}$ before implantation. Then, 4 days after implantation of the pumps (day 4) animals were anaesthetized with methohexital $(50 \mathrm{mg} / \mathrm{kg})$ and the left kidney was exposed by an abdominal incision. In five furosemide and in five vehicle-treated animals, sterile silver clips (Degussa, Germany) with an inner diameter of $0.2 \mathrm{~mm}$ were then placed on the left renal artery, in the other five furosemide and vehicle-treated animals kidneys were touched only with a forceps (sham clipped). After the operation, animals were awakened within a few minutes from narcosis. Then, $48 \mathrm{~h}$ after application of the clips (day 6) animals were killed by decapitation, because in previous experiments (Schricker et al., submitted) we found a maximal increase of renin mRNA levels $48 \mathrm{~h}$ after setting the clips. During the time of the experiment systolic blood pressure was measured with a BP recorder (Rhema, Hofheim, Germany) on day 0 (before implantation of the osmotic pump), on day 4 (before clipping of the left renal artery) and on day 6 .

Processing of the kidneys. Five animals of each group were processed for determination of plasma renin activity (PRA) and assay of renal renin mRNA. To this end animals were sacrificed by decapitation and blood was collected from the carotid arteries for determination of PRA and plasma sodium concentration and both kidneys were rapidly removed, weighed, cut in half and frozen in liquid nitrogen for extraction of total RNA.

Determination of preprorenin $m R N A$. Total RNA was extracted from the right kidneys which were stored at $-70^{\circ} \mathrm{C}$, according to the protocol by Chomczynski et al. [4] by homogenization in $10 \mathrm{ml}$ of solution $\mathrm{D}[4 \mathrm{mM}$ guanidine thiocyanate, containing $0.5 \% \mathrm{~N}$ lauryl-sarcosinate, $10 \mathrm{mM}$ ethylenediaminetetraacetate (EDTA), $25 \mathrm{mM}$ sodium citrate, $700 \mathrm{mM} \beta$-mercaptoethanol] with a polytron homogenizer. Sequentially, $1 \mathrm{ml}$ of $2 \mathrm{M}$ sodium acetate $(\mathrm{pH} \mathrm{4}), 10 \mathrm{ml}$ of phenol (water saturated) and $2 \mathrm{ml}$ of chloroform were added to the homogenate, with thorough mixing after addition of each reagent. After cooling on ice for 15 min samples were centrifuged at $10,000 \mathrm{~g}$ for $15 \mathrm{~min}$ at $4^{\circ} \mathrm{C}$. RNA in the supernatant was precipitated with an equal volume of isopropanol at $-20^{\circ} \mathrm{C}$ for at least $1 \mathrm{~h}$. After centrifugation RNA pellets were resuspended in $0.5 \mathrm{ml}$ of solution $\mathrm{D}$, again precipitated with an equal volume of isopropanol at $-20^{\circ} \mathrm{C}$ and RNA pellets finally dissolved in diethylpyrocarbonate water and stored at $-80^{\circ} \mathrm{C}$ till further processing. Renin mRNA was measured by RNase protection as described for erythropoietin [18]. A preprorenin cRNA probe containing 296 base pairs of exon I and II, generated from a pSP64 vector carrying a Pst $\mathrm{I}-K p n \mathrm{I}$ restriction fragment of a rat prepronin cDNA [2] was generated by transcription with SP6 RNA polymerase (Amersham, Amersham, UK). Transcripts were continuously labelled with $\left[\alpha^{32} \mathrm{P}\right] \mathrm{GTP}$ (where GTP is guanosine triphosphate, $1.5 \times 10^{13} \mathrm{~Bq} / \mathrm{mmol}$ or $410 \mathrm{Ci} / \mathrm{mmol}$; Amersham) and purified on a Sephadex G50 spun column. For hybridization total kidney RNA was dissolved in a buffer containing $80 \%$ formamide, $40 \mathrm{mM}$ piperazine- $N, N^{\prime}$-bis(2-ethane sulphonic acid), $400 \mathrm{mM} \mathrm{NaCl}, 1 \mathrm{mM}$ EDTA (pH 8). Then, $20 \mu \mathrm{g}$ RNA were hybridized in a total volume of $50 \mu \mathrm{l}$ at $60^{\circ} \mathrm{C}$ for $12 \mathrm{~h}$ with $8.3 \mathrm{kBq}$ $\left(5 \times 10^{5} \mathrm{cpm}\right)$ radiolabelled renin probe. RNase digestion with RNase $\mathrm{A}$ and $\mathrm{T} 1$ was carried out at $20^{\circ} \mathrm{C}$ for $30 \mathrm{~min}$ and terminated by incubation with proteinase $\mathrm{K}(0.1 \mathrm{mg} / \mathrm{ml})$ and sodium dodecylsulphate $(0.4 \%)$ at $37^{\circ} \mathrm{C}$ for $30 \mathrm{~min}$. Protected renin $\mathrm{mRNA}$ fragments were purified by phenol/chloroform extraction, ethanol precipitation and subsequent electrophoresis on a denaturing $10 \%$ polyacrylamide gel. After autoradiography of the dried gel at $-70^{\circ} \mathrm{C}$ for $1-2$ days bands representing protected renin mRNA fragments were excised from the gel and radioactivity was counted with a liquid scintillation counter (1500 Tri-CarbTm, Packard Instrument Company, Downers Grove, IU., USA). The number of counts per minute obtained from each sample of total kidney RNA was expressed relative to an external renin mRNA standard included in each hybridization, consisting of $20 \mu \mathrm{g}$ pooled RNA extracted from the 12 kidneys of six normal Sprague Dawley rats.

Determination of actin $m R N A$. The abundance of rat cytoplasmatic $\beta$-actin mRNA in total RNA isolated from the kidneys was determined by RNase protection assay exactly as described for preprorenin. An actin cRNA probe containing the 76 nucleotide first exon and around 200 base pairs of the surrounding sequence was generated by transcription with SP6 polymerase from a pAM19 vector carrying a AvaL/HindIII restriction fragment of actin cDNA [18]. For one assay $2.5 \mu \mathrm{g}$ RNA were hybridized under the conditions described for the determination of renin mRNA.

Plasma renin activity ( $P R A)$. This was determined utilizing a commercially available radioimmunoassay kit for angiotensin I (Sorin Biomedica, Düsseldorf, Germany).

Determination of plasma sodium concentration. Plasma sodium concentration was measured by flame photometry (Flame photometer, Eppendorf, Hamburg, Germany).

Statistics. ANOVA test was used for interindividual comparisons and Student's paired $t$-test for intraindividual comparisons. $P<0.05$ was considered significant.

\section{Results}

Chronic subcutaneous infusion of furosemide increased urine output in the animals from 8 to $47 \mathrm{ml} /$ day (Table 1). Kidney masses increased slightly during furosemide infusion (Table 1). To avoid salt and water loss and in consequence volume contraction, the rats had free access to chow, salt water $(0.9 \% \mathrm{NaCl}, 0.1 \% \mathrm{KCl})$ and water. Neither plasma sodium concentration nor blood pressure were changed in furosemide-treated animals (Table 1, Fig. 1, upper panel), which increased their body weights by $25.2 \pm 3.5 \mathrm{~g}$ during the 6 days of furosemide infusion. Clipping the left renal arteries with 0.2 - 
Table 1. Effect of furosemide $(12 \mathrm{mg} /$ day $)$ on urine output, plasma sodium concentration, body weight gain and kidney masses

\begin{tabular}{|c|c|c|c|c|}
\hline \multirow[t]{2}{*}{ Variable } & \multicolumn{4}{|c|}{ Group } \\
\hline & \multicolumn{2}{|c|}{ Control } & \multicolumn{2}{|c|}{ Furosemide } \\
\hline $\begin{array}{l}\text { Urine output } \\
\text { (ml/day) }\end{array}$ & \multicolumn{2}{|c|}{$8.3 \pm 2.7$} & \multicolumn{2}{|c|}{$46.9 \pm 8.0^{*}$} \\
\hline $\begin{array}{l}\text { Plasma sodium } \\
\text { concentration } \\
(\mathrm{nmol} / \mathrm{l})\end{array}$ & 144 & \pm 4 & \multicolumn{2}{|c|}{$150 \pm 3$} \\
\hline $\begin{array}{l}\text { Body weight gain } \\
\text { (g/6 day) }\end{array}$ & 54 & \pm 5.8 & \multicolumn{2}{|c|}{$25.2 \pm 3.5^{*}$} \\
\hline $\begin{array}{l}\text { Kidney masses } \\
\quad(\mathrm{mg})\end{array}$ & $\begin{array}{l}R \\
1037 \\
\pm 75\end{array}$ & $\begin{array}{l}\mathrm{L} \\
1007 \\
\pm 62\end{array}$ & $\begin{array}{l}R \\
1195 \\
\pm 38\end{array}$ & $\begin{array}{l}\mathrm{L} \\
1185^{*} \\
\pm 35\end{array}$ \\
\hline
\end{tabular}

Data are expressed as means \pm SEM of five animals in each experimental group. ${ }^{*} P<0.05$ vs vehicle-treated animals. $R$, Right; $L$, Left

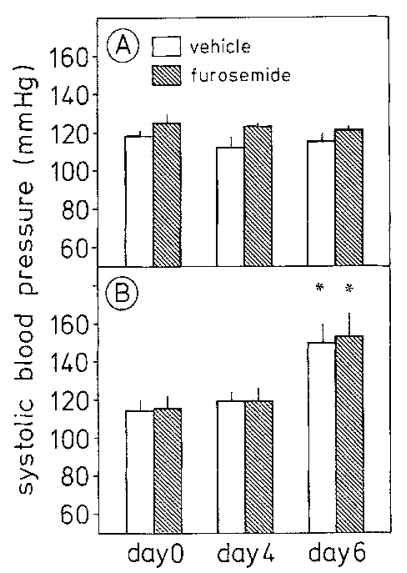

Fig. 1. A Systolic blood pressure of rats before setting of the infusion pumps (day 0 ), before sham operation (day 4 ) and $48 \mathrm{~h}$ after sham operation (day 6 ) during vehicle and furosemide infusion. $\mathbf{B}$ Systolic blood pressure of rats before setting of the infusion pumps (day 0 ), before application of the left renal artery clip (day 4 ) and $48 \mathrm{~h}$ after application of the clip (day 6). Data are means \pm SEM of five animals in each experimental group. $* P<0.05$ versus day 4

mm clips led to an increase of systolic pressure to about $150 \mathrm{~mm} \mathrm{Hg}(20 \mathrm{kPa})$ after 2 days both in vehicle- and in furosemide-infused animals (Fig. 1, lower panel).

Furosemide infusion markedly increased PRA from 10 to $47 \mathrm{ng}$ angiotensin $\mathrm{I} \mathrm{h}^{-1} \mathrm{ml}^{-1}$ (Fig. 2).

Unilateral renal artery clipping increased PRA values to $37 \mathrm{ng}$ angiotensin $\mathrm{h}^{-1} \mathrm{ml}^{-1}$ in vehicle-infused rats but did not further elevate PRA values ( $45 \mathrm{ng}$ angioten$\sin \mathrm{h}^{-1} \mathrm{ml}^{-1}$ ) in furosemide-treated animals (Fig. 2).

Renin mRNA levels in the kidneys were analysed by RNase protection. RNase protection assays for renin mRNA in total RNA were performed using a 296 base pair antisense riboprobe of rat preprorenin mRNA. Figure 3 shows a representative autoradiograph of such a renin RNase protection assay for total RNA from the left and right kidneys isolated from a nonclipped vehicleinfused, left-side clipped vehicle-infused, a nonclipped furosemide-infused and a left-side clipped furosemide-

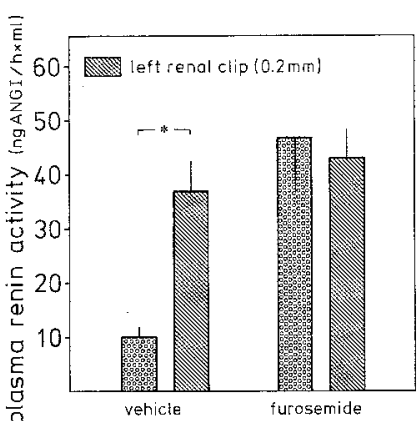

Fig. 2. Plasma renin activities (PRA) of sham-clipped vehicle-infused (column 1), clipped vehicle-infused (column 2), shamclipped furosemide-infused (column 3) and clipped furosemideinfused (column 4) rats. Data are means \pm SEM of five animals in each experimental group. ${ }^{*} P<0.05 ;$ ANG I, angiotensin I

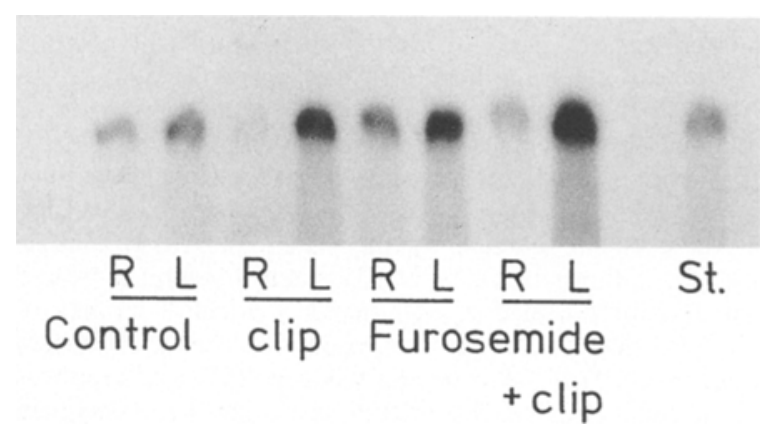

Fig. 3. Autoradiograph of RNase protection assay for renin $\mathrm{mRNA}$ with total renal RNA isolated from a vehicle-infused sham-clipped (Control), vehicle-infused clipped (clip), furosemide-infused sham-clipped and furosemide-infused clipped rat. $20 \mu \mathrm{g}$ of total RNA were analysed in each assay. $R$, Right (contralateral) kidney; $L$, left (clipped) kidney; St., $20 \mu \mathrm{g}$ of RNA

infused rat. For comparison and quantification $20 \mu \mathrm{g}$ of an aliquot from a pool of total RNA isolated from 12 kidneys of 6 normal adult male rats was coanalysed on the gel as an external standard (St). It is evident from Fig. 3 that renin mRNA was increased in the kidneys from the furosemide-infused nonclipped rat when compared with the nonclipped vehicle-infused animal. Left renal artery clipping led to a marked increase of renin mRNA in the clipped kidney and to a suppression of renin mRNA in the contralateral kidney of vehicle-infused rats. In the furosemide-infused animals clipping led to a further increase of renin mRNA in the ipsilateral kidney and to a somewhat attenuated suppression in the contralateral kidneys. For further quantification protected fragments were excised from the dried gels and measured by $\beta$-counting. After background subtraction the radioactivity of each band was related to that of the external standard RNA and expressed as percentage of the standard. Average renin mRNA levels that were quantified in this way for left and right kidneys isolated from the rats of the four experimental groups are summarized in Fig. 4.

In nonclipped animals there was no systematic side difference of renin mRNA levels between the two kidneys and furosemide infusion led to a 2.5-fold increase of basal renin mRNA levels (Fig. 4). In vehicle-infused 


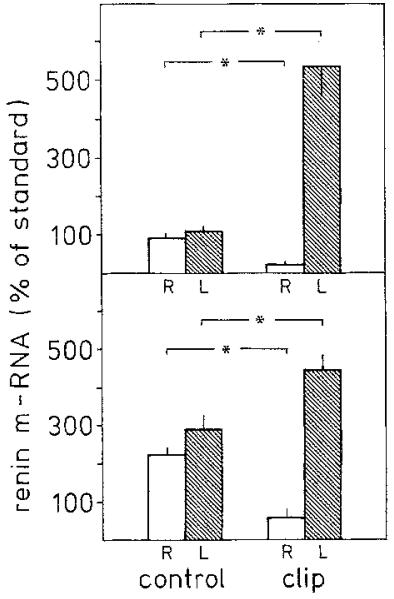

Fig. 4. Upper panel shows renal renin mRNA levels expressed in relation to an external standard in sham-clipped vehicle-infused and clipped vehicle-infused rats. Lower panel shows renal renin mRNA levels expressed in relation to an external standard in sham-clipped furosemide-infused and clipped furosemide-infused rats. Data are means \pm SEM of five animals in each experimental group $* P<0.05 . R$, Right (contralateral) kidney; $L$, left (clipped) kidney

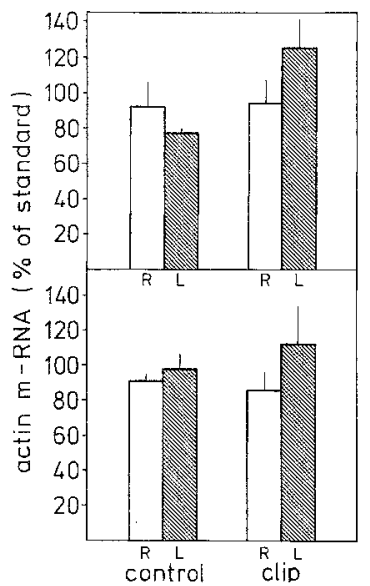

Fig. 5. Upper panel shows renal actin mRNA levels expressed in relation to an external standard in sham-clipped vehicle-infused and clipped vehicle-infused rats. Lower panel shows renal actin mRNA levels expressed in relation to an external standard in sham-clipped furosemide-infused and clipped furosemide-infused rats. Data are means $\pm S E M$ of five animals in each experimental group. ${ }^{*} P<0.05, R$, right (contralateral) kidney; $L$, left (clipped) kidney

rats clipping of the left renal artery with a $0.2-\mathrm{mm}$ clip increased renin mRNA levels to the 5-fold value of the basal level in the clipped kidney and decreased mRNA levels to $16 \%$ of the basal level in the contralateral right kidneys (Fig. 4). In furosemide-infused animals renin mRNA levels rose to similar absolute levels as in vehicle-infused rats in the clipped kidneys and decreased to $20 \%$ of the respective basal value in the contralateral kidneys.

For control we also analysed the expression of a house-keeping gene such as $\beta$-actin in vehicle- and furosemide-treated rats. As shown in Fig. 5 there was a tendency towards higher actin mRNA levels in the clipped kidneys of both vehicle- and furosemide-infused animals. There was, however, no difference of actin mRNA levels between vehicle- and furosemide-infused rats.

\section{Discussion}

This study was done to examine a possible involvement of the macula densa mechanism in the regulation of renal renin gene expression in 2-kidney/1-clip rats.

To inhibit thick ascending limb and macula densa transport function we used the loop diuretic furosemide, which was effective as indicated by the high urine flow rates. A relevant side effect of furosemide with regard to the renin system is a volume contraction induced by the marked loss of salt and water [23]. To avoid such a volume contraction the animals were allowed to have free access to salt and water. This regimen in fact prevented decreases of plasma sodium concentration and of blood pressure during furosemide treatment (Table 1 , Fig. 1). These observations are thus in good accordance with the recent demonstration that free access to salt and water maintains normal sodium balance and blood pressure in adrenalectomized, hormone-supplemented rats during chronic furosemide infusion [8]. It appears reasonable to assume therefore that the observed effects of furosemide on renin secretion and renin gene expression were due to a more specific renal effect of the drug rather than to a side effect such as volume contraction, sodium depletion or a fall of blood pressure.

The observation that furosemide increased PRA values and renin mRNA levels is in keeping with several previous papers $[1,3,6,12,14]$ and suggests that inhibition of salt transport by the thick ascending limb of Henle, including the macula densa, stimulates both renin secretion and renin gene expression. Moreover, we have recently provided evidence that inhibition of macula densa salt transport leads to a recruitment of renin producing cells in the kidneys [14]. The observation that clipping of one renal artery increased renin secretion as indicated by the elevated PRA values confirms previous in vivo and in vitro reports $[15,17]$. Also the increase of renin mRNA levels in the ipsilateral kidneys and the suppression of renin mRNA levels in the contralateral kidneys is in accordance with results obtained by others $[13,15,19]$ and ourselves [5]. Our findings now show that furosemide treatment did not further increase systemic PRA values, nor renin mRNA levels in the ipsilateral clipped kidneys whilst there again occurred a marked suppression of renin mRNA levels in the contralateral kidneys.

These findings do indicate that the stimulations of renin gene expression by low perfusion pressure and by inhibition of the macula densa salt transport are not additive and could suggest therefore that they share a common pathway. It may be argued that clipping of the renal arteries had already caused a maximal stimulation of renin gene expression, thus precluding any additive effect of furosemide. It has, however, been demonstrated recently that furosemide treatment in combination with a low salt diet led to a 13 -fold increase of renal renin 
mRNA levels in conscious rats [12], indicating that renin gene expression had not reached its upper limit in the clipped kidneys in our study. Thus our results would be compatible with the idea that the macula densa mechanism contributes to the pressure control of renin gene expression.

In the contraletaral kidneys furosemide treatment did not prevent the suppression of renin gene expression, where renin mRNA levels decreased in proportion, as in vehicle-infused animals. This suggests that the macula densa mechanism is not essentially involved in this process.

The mechanisms leading to suppression of renin gene expression in contralaterals to stenosed kidneys have not yet been unequivocally elucidated. It is speculated that an enhanced systemic generation of angiotensin II, which is a well known suppressor of renin gene expression $[7,10,16,21]$, due to increased release of renin from the stenosed kidney, is causally involved in this process [17]. It should be of interest in this context that contralateral suppression of renin gene expression occurred also in furosemide-infused animals, in which PRA values did not further increase upon renal artery clipping. This may indicate that the enhancement of systemic renin activity is not the only mechanism by which unilateral renal artery stenosis leads to contralateral suppression of renin mRNA levels. Similarly, clipping of unilateral renal artery led to a significant increase of blood pressure in furosemide-infused animals, although PRA values did not increase further. In consequence one could speculate about the existence of a second factor which is released from hypoperfused kidneys and that acts in combination with an increased systemic renin activity to cause hypertension and contralateral suppression of renin gene expression.

Acknowledgements. We thank R. Metzger, Heidelberg, Germany for providing us with the rat preprorenin cDNA and P. Ratcliffe, Oxford, UK, for providing us with rat $\beta$-actin cDNA. The expert technical and graphical assistance provided by K. H. Götz, M. L. Schweiger and the secretarial help provided by $\mathrm{H}$. Trommer is gratefully acknowledged. This study was financially supported by a grant from the Deutsche Forschungsgemeinschaft (Ku 859/2-1).

\section{References}

1. Barrett GL, Morgan TO, Alcorn D (1990) Stimulation of renin synthesis in the hydronephrotic kidney during sodium depletion. Pflügers Arch 415:774-776

2. Burnham CE, Hawelu-Johnson CL, Frank BM, Lynch KR (1987) Molecular cloning of rat renin cDNA and its gene. Proc Natl Acad Sci USA 84:5605-5609

3. Chen M, Schnerman J, Malvan RL, Killen PD, Briggs JP (1993) Time course of stimulation of renal renin m-RNA by furosemide. Hypertension 21:36-41

4. Chomczynski P, Sacchi N (1986) Single-step method of RNA isolation by acid guanidinium thiocyanate-phenol-chloroform extraction. Anal Biochem 162:156-159
5. Holmer H, Eckhardt KU, Aedtner O, LeHir M, Schricker K, Hamann M, Götz KH, Riegger G, Moll W, Kurtz A (1993) Which factor mediates reno-renal control of renin gene expression? J Hypertens (in press)

6. Ingelfinger JR, Pratt RE, Ellison K, Dzau VJ (1986) Sodium regulation of angiotensinogen mRNA expression in rat kidney cortex and medulla. J Clin Invest 78:1311-1315

7. Johns DW, Peach MJ, Gomez RA, Inagami T, Carey RM (1990) Angiotensin II regulates renin gene expression. Am J Physiol 259:F882-F887

8. Kaissling B, Stanton BA (1988) Adaptation of distal tubule and collecting duct to increased sodium delivery. I. Ultrastructure. Am J Physiol 255:F1256-F1268

9. Keeton K, Campbell WB (1981) The pharmacologic alteration of renin release. Pharmacol Rev 31:81-227

10. Kohara K, Broshihan KB, Ferrario CM, Milsted A (1992) Peripheral and central angiotensin II regulates expression of genes of the renin-angiotensin system. Am J Physiol 262: E651-E657

11. Lorenz JN, Weihprecht H, Schnermann J, Skott O, Briggs JP (1991) Renin release from isolated juxtaglomerular apparatus depends on macula densa chloride transport. Am J Physiol 260:F486-F493

12. Ludwig G, Ganten D, Murakami K, Fasching U, Hackenthal E (1987) Relationship between renin mRNA and renin secretion in adrenalectomized, salt depleted or converting enzyme inhibitor-treated rats. Mol Cell Endocrinol 50:223229

13. Makrides SC, Mulinari R, Zannis VI, Gavras H (1988) Regulation of renin gene expression in hypertensive rats. Hypertension $12: 405-410$

14. Modena B, Holmer S, Eckhardt KU, Schricker K, Riegger G, Kaissling B, Kurtz A (1993) Furosemide stimulates renin expression in the kidneys of salt balanced rats. Pflügers Arch (in press)

15. Moffett RB, McGowan RA, Gross KW (1986) Modulation of kidney renin messenger RNA levels during experimentally induced hypertension. Hypertension 8:874-882

16. Nakamura A, Iwao H, Fukui K, Kimura S, Tamaki T, Nakanishi S, Abe Y (1990) Regulation of liver angiotensinogen and kidney renin mRNA levels by angiotensin II. Am J Physiol 258: E1-E6

17. Ploth DW (1983) Angiotensin-dependent renal mechanisms in two-kidney one-clip renal vascular hypertension. Am J Physiol 245: F131-F141

18. Ratcliffe PJ, Jones RW, Philipps RE, Nicholls LG, Bell JI (1990) Oxygen-dependent modulation of erythropoietin mRNA levels in isolated rat kidneys studied by RNase protection. J Exp Med 172:657-660

19. Samani MJ, Godfrey MJ, Major JS, Brammar WJ, Swales JD (1989) Kidney renin m-RNA levels in the early and chronic phases of two kidney, one-clip hypertension in the rat. $J$ Hypertens 7:105-112

20. Scholz H, Vogel U, Kurtz A (1993) Interrelation between baroreceptor and macula densa mechanisms in the control of renin secretion. J Physiol (Lond) (in press)

21. Schunkert H, Ingelfinger JR, Jacob H, Jackson B, Bouyounes H, Dzau VJ (1992) Reciprocal feed back regulation of kidney angiotensinogen and renin mRNA expression by angiotensin II. Am J Physiol 263:E863-E869

22. Vander AJ (1967) Control of renin release. Physiol Rev 47: $359-382$

23. Wilcox CS, Mitch WE, Kelly RA, Friedman PA, Souney P, Rayment CM, Meyer TW, Skorecki K (1984) Factors affecting potassium balance during furosemide administration. Clin Sci $67: 196-203$ 